УДК 616.37-002.1-092-07-085

DOI: $10.24061 / 1727-0847.18 .3 .2019 .16$

\title{
В.В. Максим'юк
}

Кафедра хірургії № 1(зав. - проф. І.Ю. Полянський) Вищзого державного навчального закладу України «Буковинський державний медичний університет», м. Чернівці

\section{СУЧАСНІ ПРИНЦИПИ ВЕДЕННЯ ХВОРИХ НА ГОСТРИЙ ПАНКРЕАТИТ}

Резюме. Напрацьовано нові та оптимізовано існуючі підходи до діагностики, прогнозування перебігу та лікування гострого панкреатиту. Застосування запропонованого діагностично-лікувального комплексу та лікувальної тактики дозволило суттєво покращати результати лікування хворих на гострий панкреатит: знизити частоту виникнення панкреатичних нориць й арозивних кровотеч на 25,7 \% та 31,0 \% відповідно; зменшити кількість повторних хірургічних інвазій на 34,0 \%; знизити частоту розвитку післяопераційних ускладнень 3 31,6 \% до 12,5\%; скоротити тривалість стаціонарного лікування у разі вогнищевого панкреонекрозу на 8 ліжко-днів; знизити летальність при поширеному панкреонекрозі 3 30,0 \% до 14,3\%. Усе це свідчить про ефективність запропонованої лікувальної тактики та доцільність ії широкого клінічного впровадження.

Ключові слова: гострий панкреатит, діагностика, лікування.

Актуальність проблеми гострого панкреатиту у медико-соціальному аспекті зумовлена висококоштовною консервативною терапією, великою частотою повторних багаторазових оперативних втручань, незадовільними результатами хірургічного лікування, високим рівнем післяопераційної летальності та інвалідизації, особливо серед осіб працездатного віку [1-5].

Мета дослідження: узагальнити та оптимізувати існуючі принципи ведення хворих на гострий панкреатит.

Матеріал і методи: Клінічний матеріал становили 408 хворих на різні форми гострого панкреатиту віком від 18 до 84 років, серед яких було 187 (43,9\%) чоловіків та 239 (56,1\%) жінок. Хворих розподіляли на дві групи: 1-а група (група порівняння) та 2-а група (основна група). До групи порівняння увійшли 196 хворих, курачія яких здійснювалось згідно діючих стандартів. Основну групу становило 212 хворих, у яких застосовували оптимізовані підходи до ведення хворих на гострий панкреатит.

Результати дослідження та їх обговорення: Основу напрацьованих підходів до оптимізації діагностики, прогнозування перебігу та лікування гострого некротичного панкреатиту становила комплексна реалізація наступних принципів.

Принцип ранньої «агресивної» інфузійної терапії, суть якого полягав у проведенні комплексу інтенсивної терапії з адекватною рідинною ресусцітацією протягом першої доби [2]. Впродовж вказаного терміну часу усім хворим проводили інтенсивну інфузійну терапію 3 розрахунку 40-50 мл/кг при швидкості введення 50-60 крапель на хвилину. Таким чином, середній об'єм інфузії впродовж перших 24 год. становив 3-5 літрів на тлі проведення форсованого діурезу.

Принцип деескалації, суть якого полягає у первинному призначенні хворим з несприятливим прогнозом максимальних доз блокаторів панкреатичної секреції (сандостатин), інгібіторів протеолітичних ферментів (контрикал) та антибіотиків широкого спектру дії останніх генерацій.

Принцип поєднаної пролонгованої антиферментної терапії, який полягає у поєднанні різних шляхів введення інгібіторів протеаз впродовж тривалого часу. На основі визначення провідних шляхів транслокації активованих панкреатичних ензимів та механізмів виникнення панкреатогенної гіперферментемії нами запропоновано проведення пролонгованої (не менше 7-и днів) внутрішньовенної (периферична вена + підключична вена + портальна вена) та ендолімфатичної (лімфатичний вузол правої пахової ділянки) антиферментної терапії за напрацьованими методиками (патенти на корисну модель № 62364, № 66673) . При цьому, дотримувались правила постійної підтримки «ефективної» концентрації інгібіторів протеаз, що досягалось їх безперервним введенням за домогою інфузомату.

Принцип паралельності, який полягає у поєднаному комплексному застосуванні повного 
об'єму лікувальних засобів з перших годин госпіталізації, не очікуючи результатів ефективності застосування лише окремого методу (антисекреторної терапії, екстракорпоральної детоксикації, хірургічної інвазії тощо).

Принцип специфічного моніторингу. У результаті досліджень встановлено, що на час госпіталізації хворих найбільш специфічними лабораторно-інструментальними проявами гострого некротичного панкреатиту були: трипсин крові $>15,3$ Мод, ліпаза крові $>196,0$ Од/л, амілаза крові > $26,0 \mathrm{mr} / \mathrm{c}^{* \pi}, \alpha_{1}$-антитрипсин крові $<10,0$ мкмоль/л, $\alpha_{2}$-макроглобулін крові $<1,10$ г/л, прокальцитонін крові $>1,7$ нг/мл, амілаза сечі $>178,0 \mathrm{mr} / \mathrm{c}^{*}$, шкала APACHE $>16$ балів, шкала SAPS $>21,0$ балів, шкала MODS > 19,0 балів, шкала SOFA > 13,5 балів, Індекс Balthazar > 3,3 бал, оптична густина плазми крові $<0,48$ од, зміщення максимальної інтенсивності флуоресценції плазми крові на довжину хвилі $\lambda<467$ нм.

Принцип мініінвазивності та мінітравматичності. При проведенні хірургічних інвазій перевагу надавали мініінвазивним (ехоконтрольовані пункційно-дренуючі) та мінітравматичним (ехоконтрольовані, відеолапароскопічні або відеолапароскопічно-асистовані) методам за чітко визначеними показами.

Принцип послідовності (каскадності). Впродовж перших діб розвитку захворювання, коли неможливо вірогідно прогнозувати «за яким сценарієм» розгорнеться перебіг гострого панкреатиту, за умов наявності відмежованих рідинних скупчень виконували ехоконтрольоване мініінвазивне їх дренування. При цьому, введенні мікроірригатори використовувались як з метою первинного дренування та локального введення антиферментних засобів, так і з метою об'єктивного контролю за станом уражених тканин, що визначалось на основі змін характеру ексудату. У тих випадках, коли на фоні проводимого комплексного лікування гострого панкреатиту, відмічались вірогідні ознаки його прогресування виконували відеолапароскопію, ревізію та санацію черевної порожнини і сальникової сумки, у порожнину якої, 3 метою адекватного дренування та пролонгованого місцевого медикаментозного впливу, підводили розроблені дренажно-сорбційні конструкції (патенти на корисну модель № 66934, № 62379, № 25832). При формуванні місцевих гнійно-некротичних ускладнень (абсцес, нагноєна псевдокиста) виконували повторну відеолапароскопію, яку, залежно від локалізації вогнища ураження, завершували формуванням відео-асистованої марсупіалізації сальникової сумки або мінітравматичної люмбостомії шляхом застосування місце- вих проекційних розрізів. У разі розвитку поширеного панкреатогенного гнійного перитоніту виконували лапаротомію, яку, після проведення основного етапу операційного втручання (некроз-, секвестректомія, санація), згідно чітко визначених показань завершували відкритим дренуванням сальникової сумки або тимчасовим закриттям операційної рани за напрацьованими методиками (патенти на корисну модель № 25280, № 30930, заявка на корисну модель № 2011 11641).

У процесі ліквідації гнійно-некротичного ураження підшлункової залози та прилеглих іiі тканин використовували зворотній принцип - товсті дренажі поетапно замінювали більш тонкими 3 поступовим їх видаленням до повного закриття панкреатичних нориць.

Принцип індивідуальної курації, який полягає у тому, що вибір методу як первинної, так і етапних хірургічних інвазій повинен визначатись у кожного хворого окремо відповідно до характеру перебігу гострого некротичного панкреатиту, його форми, фази, виду ускладнень та багатьох інших факторів (тяжкість стану, поєднана патологія, наявність акустичного вікна тощо).

Принцип пролонгованого антиферментного та антибактеріального місцевого впливу. 3 метою пригнічення агресивності протеолітичного ураження панкреатичної паренхіми та суміжних тканин, а також для профілактики та лікування гнійно-некротичних ускладнень гострого панкреатиту нами напрацьовано нові дренажно-сорбційні пристрої, методи перитонео- та вульнеосорбції (патенти на корисну модель № 66934, № 66654 , № 30930, № 28280). Застосування останніх характеризується використанням сорбенту з наведеними антиферментними та антибактеріальними властивостями, що дозволяє ефективно попереджувати ушкоджуючу дію місцевих альтераційних чинників та їх розповсюдження.

Принцип висококваліфікованої лікарської універсальності, дотримання якого вимагає від хірурга одночасного досконалого володіння декількома лікарськими спеціальностями - хірургія, ендоскопія, інтенсивна терапія, ультразвукова та рентгенодіагностика. Це дозволяе зберігати цілісність розуміння проблем лікування на різних етапах його проведення.

Принцип висококваліфікованої вузькоспеціалізованої централізації (принцим інструментальної акумуляції). Сучасні підходи до діагностики та лікування гострого панкреатиту диктують необхідність застосування новітніх технологій, які грунтуються на комплексному використанні спеціалізованого дороговартісного медичного обладнання (аналізатори біологічних рідин, устатку- 
вання для проведення генетичних досліджень, КТ, МРТ, УЗД, ендоскопічне та рентгенологічне обладнання, набори спеціального інструментарію та багато іншого). Також, необхідною умовою реалізації наведених вище принципів є високопрофесійне уміння хірургом аналітично оцінити зміни багатьох діагностично-прогностичних маркерів гострого панкреатиту та володіння широким спектром різноманітних операційних втручань (мініівазивні, ендоскопічні, відкриті). Зрозуміло, що комплексне поєднання вказаних складових, необхідних для ефективного лікування гострого некротичного панкреатиту, можливе тільки в умовах спеціалізованих відділень (центрів) висококваліфікованих вузькоспеціалізованих медичних закладів, де і повинні лікуватись такі хворі.

Висновок. Застосування напрацьованих підходів дозволило зменшити кількість післяопераційних ускладнень 3 31,6 \% до 12,5 \%, скоротити тривалість стаціонарного лікування у разі вогнищевого панкреонекрозу на 8 ліжко-днів, знизити летальність при поширеному панкреонекрозі 3 $30,0 \%$ до $14,3 \%$.

Перспективи подальших досліджень. Полягають в подальшому напрацюванні ефективних методів лікування гострого панкреатиту.

\section{Список використаної літератури}

1. Годлевський AI, Саволюк CI, Томашевський ЯВ. Оптимізачія лікувально-діагностичних та тактичних принциипів курації гострого панкреатиту біліарної етіології у хворих з иукровим діабетом. Вісник Вінницького національного медичного університету. 2014;2:210-4.

2. Ashley SW. The management of pancreatic necrosis continues to evolve, and this has been accompanied by significant improvements in outcomes. Foreword. Curr. Probl Surg. 2014;51:369.

3. Akinosoglou K, Gogos C. Immune-modulating therapy in acute pancreatitis: Fact or fiction. World J Gastroenterol. 2014;20:15200-15.

4. Bakker J, Issa Y, van Santvoort HC. Treatment options for acute pancreatitis. Nature Reviews Gastroenterology and Hepatology. 2014;11:462-9.

5. Puri R, Thandassery RB, Alfadda AA, Kaabi SA. Endoscopic ultrasound guided drainage of pancreatic fluid collections: Assessment of the procedure, technical details and review of the literature. World J. Gastrointest. Endosc. 2015;16:354-63.

\section{References}

1. Hodlevs'kyy AI, Savolyuk SI, Tomashevs'kyy YaV. Optymizatsiya likuval'no-diahnostychnykh ta taktychnykh pryntsypiv kuratsiyi hostroho pankreatytu biliarnoyi etiolohiyi u khvorykh z tsukrovym diabetom [Optimization of medical-diagnostic and tactical principles of curation of acute pancreatitis of biliary etiology in patients with diabetes mellitus]. Visnyk Vinnyts'koho natsional'noho medychnoho universytetu. 2014;2:210-4. (in Ukrainian).

2. Ashley SW. The management of pancreatic necrosis continues to evolve, and this has been accompanied by significant improvements in outcomes. Foreword. Curr. Probl Surg. 2014;51:369.

3. Akinosoglou K, Gogos C. Immune-modulating therapy in acute pancreatitis: Fact or fiction. World J Gastroenterol. 2014 Nov 7;20(41):15200-15. doi: 10.3748/wjg.v20.i41.15200.

4. Bakker J, Issa Y, van Santvoort HC. Treatment options for acute pancreatitis. Nat Rev Gastroenterol Hepatol. 2014 Aug;11(8):462-9. doi: 10.1038/nrgastro.2014.39.

5. Puri R, Thandassery RB, Alfadda AA, Kaabi SA. Endoscopic ultrasound guided drainage of pancreatic fluid collections: Assessment of the procedure, technical details and review of the literature. World J Gastrointest Endosc. 2015 Apr 16;7(4):354-63. doi: 10.4253/wjge.v7.i4.354.

\section{СОВРЕМЕННЫЕ ПРИНЦИПЫ ВЕДЕНИЯ БОЛЬНЫХ ОСТРЫМ ПАНКРЕАТИТОМ}

Резюме. Наработаны новые и оптимизированы существующие подходы к диагностике, прогнозированию течения и лечения острого панкреатита. Применение предложенного лечебного-диагностического комплекса и лечебной тактики позволило существенно улучшить результаты лечения больных острым панкреатитом: снизить частоту возникновения панкреатических свищей и арозивних кровотечений на 25,7 \% и 31,0 \% соответственно; уменьшить количество повторных хирургических инвазий на 34,0 \%; снизить частоту развития послеоперационных осложнений с 31,6 \% до 12,5 \%; сократить продолжительность стационарного лечения в случае очагового панкреонекроза на 8 койко-дней снизить летальность при распространенном панкреонекрозе с 30,0 \% до 14,3 \%. Все это свидетельствует об эффективности предложенной лечебной тактики и целесообразность ее широкого клинического применения.

Ключевые слова: острый панкреатит, диагностика, лечение. 


\section{MODERN PRINCIPLES OF MANAGEMENT OF PATIENTS WITH ACUTE PANCREATITIS}

Abstract. New and optimized existing approaches to the diagnosis, prognosis and treatment of acute necrotic pancreatitis have been developed. Implementation of the suggested treatment strategy and therapeutic tactics enabled to improve substantially results of treatment of patients with acute pancreatitis: decrease rate of occurrence of pancreatic fistulas and erosive bleeding by $25.7 \%$ and $31.0 \%$ respectively, number of repeated surgical invasion by $34.0 \%$, frequency of postoperative complications from $31.6 \%$ to $12.5 \%$, hospital stay in case of focal pancreatonecrosis by 8 days, mortality rate in patients with generalized pancreatonecrosis from $30.0 \%$ to $14.3 \%$. All this is indicative of the effectiveness of the suggested therapeutic tactics and reasonability of its wide clinical implementation.

Key words: acute pancreatitis, diagnosis, treatment.

Відомості про автора:

Максим'юк Віталій Васильович - доктор медичних наук, професор кафедри хірургії № 1 Вищого державного навчального закладу України «Буковинський державний медичний університет», м. Чернівці.

Information about author:

Maksymyuk Vitaliy V. - Doctor of Medical Sciences, Professor Department of Surgery № 1 Higher State Educational Establishment of Ukraine «Bukovinian State Medical University», Chernivtsi.

Надійшла 12.03.2019 p. Рецензент - проф. Беденюк А.Д. (Тернопіль) 